\title{
Phylogeny of the Sphaerotilus-Leptothrix Group Inferred from Morphological Comparisons, Genomic Fingerprinting, and 16S Ribosomal DNA Sequence Analyses
}

\author{
PATRICIA L. SIERING AND WILLIAM C. GHIORSE* \\ Section of Microbiology, Division of Biological Sciences, Cornell University, Ithaca, New York 14853-8101
}

\begin{abstract}
Phase-contrast light microscopy revealed that only one of eight cultivated strains belonging to the Sphaerotilus-Leptothrix group of sheathed bacteria actually produced a sheath in standard growth media. Two Sphaerotilus natans strains produced branched cells, but other morphological characteristics that were used to identify these bacteria were consistent with previously published descriptions. Genomic fingerprints, which were obtained by performing PCR amplification with primers corresponding to enterobacterial repetitive intergenic consensus sequences, were useful for distinguishing between the genera Sphaerotilus and Leptothrix, as well as among individual strains. The complete $16 \mathrm{~S}$ ribosomal DNA (rDNA) sequences of two strains of "Leptothrix discophora" (strains SP-6 and SS-1) were determined. In addition, partial sequences (approximately 300 nucleotides) of one strain of Leptothrix cholodnii (strain LMG 7171), an unidentified Leptothrix strain (strain NC-1), and four strains of Sphaerotilus natans (strains ATCC $13338^{\mathbf{T}}$ [T = type strain], ATCC 15291, ATCC 29329, and ATCC 29330) were determined. We found that two of the $S$. natans strains (ATCC 15291 and ATCC $13338^{\mathrm{T}}$ ), which differed in morphology and in their genomic fingerprints, had identical sequences in the 300-nucleotide region sequenced. Both parsimony and distance matrix methods were used to infer the evolutionary relationships of the eight strains in a comparison of the 16S rDNA sequences of these organisms with 16S rDNA sequences obtained from ribosomal sequence databases. All of the strains clustered in the Rubrivivax subdivision of the $\beta$ subclass of the Proteobacteria, which confirmed previously published conclusions concerning selected individual strains. Additional analyses revealed that all of the $S$. natans strains clustered in one closely related group, while the Leptothrix strains clustered in two separate lineages that were approximately equidistant from the $S$. natans cluster. This finding suggests that the tentative species " $L$. discophora" needs to be more clearly defined and compared with other species belonging to the genus Leptothrix.
\end{abstract}

Sheath-forming bacteria are found in several disparate bacterial groups, including the nonfruiting gliding bacteria, the cyanobacteria, and the methanogens. In Bergey's Manual of Systematic Bacteriology the following seven genera are described under the heading "Sheathed Bacteria" (36): Sphaerotilus, Leptothrix, Crenothrix, Phragmidiothrix, Haliscomenobacter, and Lieskeella. These taxa are distinguished primarily on the basis of morphological criteria. The sheathed bacteria that have been described (36) include five Leptothrix species (34), Sphaerotilus natans (35), and Haliscomenobacter hydrossis (33). The latter two species and two Leptothrix spp. ("Leptothrix discophora" and Leptothrix cholodnii) are available from culture collections. The type species of the genus Leptothrix, Leptothrix ochracea, is frequently observed in natural systems containing iron bacteria $(20,22,40)$ but has never been cultivated successfully and therefore is not available in axenic culture (34). The other Leptothrix species that have been described, "Leptothrix pseudo-ochracea" and Leptothrix lopholea, are not, to our knowledge, available from culture collections. Recently, the results of DNA-rRNA hybridization experiments (53) and $5 \mathrm{~S}$ and $16 \mathrm{~S}$ rRNA sequence analyses $(8,29)$ have been used to place $L$. cholodnii, "L. discophora," and $S$. natans in the $\beta-1$ subgroup of the Proteobacteria, and the results of a phylogenetic analysis of small-subunit rRNA (19) have been used to place $H$. hydrossis in the saprospira subgroup of the "flavobacter-bacteroides" phylum.

The genera Sphaerotilus and Leptothrix have always been considered closely related (20). Indeed, these taxa are fre-

* Corresponding author. Phone: (607) 255-3086. Fax: (607) 2553904. Electronic mail address: wcg1@cornell.edu. quently referred to collectively as the Sphaerotilus-Leptothrix group. While the distinction between these two genera has been debated for many years (20), there has been no comprehensive phylogenetic analysis in which the closely related organisms belonging to this group have been compared.

A powerful method for such an analysis is 16S rRNA sequence comparison. This method has recently become an important tool for estimating phylogenetic and evolutionary relationships among organisms $(38,39,50,55)$. However, inferring phylogenetic relatedness from the results obtained with this method is not necessarily a straightforward process. There have been many investigations of the accuracy of the methods used to infer phylogenetic relatedness $(24,25,41,45)$. For closely related organisms (i.e., when the rates of evolutionary change are low), the results of most methods may converge on the "correct" answer, especially when enough data are used. However, the quantity of data needed for "correct" phylogenetic inferences may vary from method to method. For example, Hillis et al. (25) examined a simulation involving four taxa evolving under a Kimura model with equal but high rates of evolution and a transition-to-transversion ratio of 10:1. They found that sequences containing as few as 200 nucleotides were sufficient when the weighted parsimony method was used, while up to 50,000 nucleotides were required when a neighbor-joining method was used. Although Hillis et al. (25) did not explicitly discuss the problem, the choice of which 200 nucleotides to use is certainly critical for the success of the weighted parsimony method. While it is desirable to analyze complete $16 \mathrm{~S}$ ribosomal DNA (rDNA) or rRNA sequences, the time-consuming nature of sequencing work has made partial sequence comparisons an attractive alternative. In recent years, several investigators have demonstrated the 
TABLE 1. Bacterial strains used and their sources

\begin{tabular}{lll}
\hline \multicolumn{1}{c}{ Taxon } & \multicolumn{1}{c}{ Strain $^{a}$} & \multicolumn{1}{c}{$\begin{array}{l}\text { Source or } \\
\text { reference }^{a}\end{array}$} \\
\hline "Leptothrix discophora" & SS-1 (= ATCC 43182) & 18 \\
"Leptothrix discophora" & SP-6 (= ATCC 51168) & 10 \\
Leptothrix sp. & NC-1 & Corstjens \\
Leptothrix cholodnii & LMG 7171 (= CCM 1827 & BCCM/ \\
& Mulder 5) & LMG \\
Sphaerotilus natans & ATCC 13338 & ATCC \\
Sphaerotilus natans & ATCC 15291 & ATCC \\
Sphaerotilus natans & ATCC 29329 & ATCC \\
Sphaerotilus natans & ATCC 29330 & ATCC \\
Escherichia coli & DH5 $\alpha \mathrm{F}^{\prime}$ & Winans $^{d}$ \\
\hline
\end{tabular}

${ }^{a}$ ATCC, American Type Culture Collection, Rockville, Md.; CCM, Czechoslovak Collection of Microorganisms, Brne, Czechoslovakia; BCCM/LMG, Belgian Coordinated Collection of Microorganisms/Laboratorium voor Microbiologie Universiteit Gent Bacterial Culture Collection, Ghent, Belgium.

${ }^{b}$ Strain NC-1 was isolated from Bear Trap Creek in Syracuse, N.Y., by Hans and Liesbeth de Vrind and Eleanora Robbins.

${ }^{c}$ Paul Corstjens, Department of Chemistry, Leiden University, Leiden, The Netherlands.

${ }^{d}$ Steve Winans, Department of Microbiology, Cornell University, Ithaca, N.Y.

utility of using partial rRNA sequences for phylogenetic inference $(3,5,29,30,56)$.

In this present study, we examined the relatedness of eight strains belonging to the Sphaerotilus-Leptothrix group. All of the strains which we used are available from culture collections or laboratories that are actively engaged in research on these bacteria. We compared these strains by using the following characteristics: presence of a sheath, cellular morphology, and genomic fingerprints. One of our major goals was to compare 16S rRNA gene sequences in order to construct a phylogeny of the group. We determined the complete $16 \mathrm{~S}$ rDNA sequences of "L. discophora" SP-6 and SS-1 and partial 16S rDNA sequences (corresponding to approximately positions 8 to 304 in the Escherichia coli 16S rRNA sequence [4]) of L. cholodnii LMG 7171, Leptothrix sp. strain NC-1, and four $S$. natans strains. We used both parsimony-based and distance matrixbased methods to construct phylogenetic trees which showed the relationships of the eight strains studied to each other and to other members of the $\beta$ subgroup of the Proteobacteria.

\section{MATERIALS AND METHODS}

Cultures and cultivation. The sources of bacterial strains used in this study are shown in Table 1. Leptothrix cultures were grown in PTYP medium, which contained (per liter of distilled deionized water $\left[\mathrm{ddH}_{2} \mathrm{O}\right]$ ) $0.25 \mathrm{~g}$ of peptone (Difco Laboratories, Detroit, Mich.), $0.25 \mathrm{~g}$ of Trypticase (BBL Becton Dickinson Microbiology Systems, Cockeysville, Md.), $0.50 \mathrm{~g}$ of yeast extract (Difco), 0.6 $\mathrm{g}$ of $\mathrm{MgSO}_{4} \cdot 7 \mathrm{H}_{2} \mathrm{O}$ (Fisher Scientific, Fairlawn, N.J.), $0.07 \mathrm{~g}$ of $\mathrm{CaCl}_{2} \cdot 2 \mathrm{H}_{2} \mathrm{O}$ (Fisher), and $2.38 \mathrm{~g}$ of HEPES ( $N$-2-hydroxyethylpiperazine- $N^{\prime}$-2-ethanesulfonic acid) buffer (United States Biochemical Corp., Cleveland, Ohio); the $\mathrm{pH}$ of this medium was adjusted to 7.2 with $\mathrm{NaOH}$ before autoclaving. Sodium pyruvate $(0.1 \%)$ and iron sulfate $(10 \mu \mathrm{M})$ were added aseptically after autoclaving from filter-sterilized and autoclaved stock solutions, respectively. For morphological comparisons of Leptothrix strains, $\mathrm{Mn}^{2+}$ was added to PTYP medium at a final concentration of $3 \mu \mathrm{g} / \mathrm{ml}$ from an autoclaved stock solution containing $300 \mu \mathrm{g}$ of $\mathrm{Mn}^{2+}$ as $\mathrm{MnSO}_{4} \cdot \mathrm{H}_{2} \mathrm{O}$ per ml. $S$. natans strains were grown in CGYA medium (18), which contained (per liter of $\mathrm{ddH}_{2} \mathrm{O}$ ) $5 \mathrm{~g}$ of Casitone (Difco), $10 \mathrm{~g}$ of glycerol, and $1 \mathrm{~g}$ of yeast extract. For morphological comparisons, these strains were grown in an unbuffered medium containing $1 \mathrm{~g}$ of peptone per liter of $\mathrm{ddH}_{2} \mathrm{O}$ and $1 \mathrm{~g}$ of glucose per liter of $\mathrm{dd}_{2} \mathrm{O}$, as recommended by Mulder (35). Liquid cultures were inoculated by transferring $100-\mu$ l portions of a 2 -day-oid culture into $25 \mathrm{ml}$ of the appropriate medium in $250-\mathrm{ml}$ flasks. The flasks were incubated at $28^{\circ} \mathrm{C}$ on a rotary shaker at $100 \mathrm{rpm}$. E. coli was grown in either Luria broth or M9 minimal liquid medium (42) at $37^{\circ} \mathrm{C}$ on a rotary shaker at $250 \mathrm{rpm}$. Ampicillin was added to a final concentration of $60 \mu \mathrm{g} / \mathrm{ml}$ when it was required for selection of transformants and maintenance of plasmids. Solid media were prepared by adding $1.5 \%$ Bacto-Agar (Difco).

Phase-contrast microscopy. Each agar-coated slide mount for photomicrog- raphy was prepared by placing $7 \mu$ l of a culture under a coverglass ( 22 by $22 \mathrm{~mm}$ ) on a 1-mm-thick glass microscope slide that previously had been coated with a film consisting of $0.75 \%$ Bacto-Agar (Difco) in dd $\mathrm{H}_{2} \mathrm{O}$ and air dried. Representative fields containing immobilized cells were photographed by using a phase-contrast $100 \times$ Plan-apochromat oil immersion objective lens (numerical aperture $[\mathrm{NA}]=1.3)$ and an oil immersion condenser lens $(\mathrm{NA}=1.4)$ mounted on a Zeiss model Standard 18 microscope equipped with a Zeiss model MC-63 35-mm camera system. The film used for the photomicrographs was Kodak TMax 100 black and white film.

Genomic fingerprinting. The PCR primers used for genomic fingerprinting (49) were designed by using each half of the core inverted repeat of the enterobacterial repetitive intergenic consensus (ERIC) sequences (26). Fingerprints were obtained by using the PCR cycling conditions and cocktail recipe described by de Bruin (10), as modified by J. B. Herrick (22a). In the modified procedure, cells from colonies (less than 1 week old) on agar plates were transferred with a platinum needle into $10 \mu \mathrm{l}$ of dd $\mathrm{H}_{2} \mathrm{O}$ in a $200-\mu \mathrm{l}$ thin-wall tube (Lab Product Sales, Rochester, N.Y.), heated at $95^{\circ} \mathrm{C}$ for $5 \mathrm{~min}$, and immediately cooled on ice. A PCR cocktail $(33.75 \mu \mathrm{l})$ was then added to the tube so that the final concentrations of the components in the $50-\mu l$ reaction mixture were as follows: $50 \mathrm{mM}$ $\mathrm{KCl}, 10 \mathrm{mM}$ Tris ( $\mathrm{pH} 8.8$ ), $1.5 \mathrm{mM} \mathrm{MgCl}, 0.1 \mathrm{mg}$ of nuclease-free bovine serum albumin (BSA) (New England Biolabs, Beverly, Mass.) per ml, 0.05\% Tween 20, $2 \mu \mathrm{M}$ primer ERIC1R (49) (Cornell Oligonucleotide Synthesis Facility, Biotechnology Institute, Cornell University, Ithaca, N.Y.), $2 \mu \mathrm{M}$ primer ERIC2 (49) (Cornell Oligonucleotide Synthesis Facility), and $4 \mathrm{U}$ of Taq polymerase (Promega Corp., Madison, Wis.) per $50 \mu$ l. Then 2 drops of sterile mineral oil were added, the solution heated to $80^{\circ} \mathrm{C}$ in a Minicycler thermocycler (MJ Research, Watertown, Mass.), and each deoxynucleoside triphosphate (dNTP) was added to a final concentration of $125 \mu \mathrm{M}$. The following cycling program was used: 7 $\min$ at $95^{\circ} \mathrm{C} ; 34$ cycles consisting of $1 \mathrm{~min}$ at $94^{\circ} \mathrm{C}, 1 \mathrm{~min}$ at $52^{\circ} \mathrm{C}$, and $8 \mathrm{~min}$ at $65^{\circ} \mathrm{C}$; and finally elongation for $16 \mathrm{~min}$ at $65^{\circ} \mathrm{C}$. A $10-\mu$ l portion of the amplification products was combined with a Ficoll-based loading dye (42) and was loaded into a $2 \%$ agarose gel containing wells made with a fine-tooth comb (tooth thickness, $0.75 \mathrm{~mm}$ ). The gel was electrophoresed at $4 \mathrm{~V} / \mathrm{cm}$ for approximately 2 to $2.5 \mathrm{~h}$ at room temperature and then stained with ethidium bromide. All PCR were performed in duplicate and repeated three times to ensure that the fingerprint band profiles were reproducible. The fingerprints generated by using whole cells (as described above) were also verified by comparing them with fingerprints generated with $50 \mathrm{ng}$ of purified chromosomal DNA isolated from each strain by standard procedures (2).

Primers used for PCR amplification and sequencing of the 16S rDNA. For PCR amplification, our 5' primer (primer P5) corresponded to primer P0mod, and our $3^{\prime}$ primer (primer P3) corresponded to primer PC5 described by Wilson et al. (54). These primers were synthesized with an additional $5^{\prime}$ linker containing restriction sites for either SalI or EcoRI (primer P5) or HindIII, BamHI, and XmaI (primer P3), as described by Weisburg et al. (52), at the Cornell Oligonucleotide Synthesis Facility.

The design of our sequencing primers was based on conserved regions of previously described $16 \mathrm{~S}$ rRNA gene sequences of eubacteria. The forward primers used were primers P5 (see above), P342 (5'-CTACGGGAGGCAG CAGT; positions 342 to 357), P520 (5'-CAGCAGCCGCGGTAATAC; positions 520 to 537), Pint (5'-ATTAGATACCCTGGTAGTCC; positions 786 to 805), P1090 (5'-TTAAGTCCCGCAACGAGCG; positions 1090 to 1108), and P1336 ( $5^{\prime}$-GGA[G, T, A]T[C, G, T]GCTAGTAATCG; positions 1336 to 1352) (E. coli numbering $[4])$. The primers used to determine sequences in the reverse direction were primers P3 (see above), P1221R (5'-CCATTGTAG[CGT]ACGT GTGT; positions 1221 to 1204), P1061R (5'-GT[C, T]GGTACGT[C, G]GTG GACA; positions 1061 to 1044), P793R (5'-GCGTGGACTACCAGGGTA; positions 793 to 776), P520R (5'-GTATTACCGCGGCTGCTG; positions 537 to 520), and P258R (5'-CTTGGT[G, A][G, A]GCC[GTA]TTACC; positions 274 to 258) (E. coli numbering [4]).

PCR amplification and cloning. The procedure used for PCR amplification of the 16S rDNA was similar to the procedure of Herrick et al. (23). Cells from colonies growing on agar plates were transferred into $10 \mu \mathrm{l}$ of dd $\mathrm{H}_{2} \mathrm{O}$, heated at $95^{\circ} \mathrm{C}$ for $5 \mathrm{~min}$, and immediately cooled on ice as described above. A PCR cocktail $(85 \mu \mathrm{l})$ was added to give the following final concentrations of components in the $100-\mu \mathrm{l}$ reaction mixture: $50 \mathrm{mM} \mathrm{KCl}, 10 \mathrm{mM}$ Tris $(\mathrm{pH} 8.8), 1.5 \mathrm{mM}$ $\mathrm{MgCl}_{2}, 0.1 \mathrm{mg}$ of nuclease-free BSA (New England Biolabs) per ml, $0.05 \%$ Tween 20, 0.25 $\mu \mathrm{M}$ primer P5, $0.25 \mu \mathrm{M}$ primer P3, and $2.5 \mathrm{U}$ of Taq polymerase (Promega Corp.) per $100 \mu$ l. After 2 drops of sterile mineral oil were added, each tube was heated to $80^{\circ} \mathrm{C}$ in a Minicycler thermocycler (MJ Research), and each dNTP was added to a final concentration of $50 \mu \mathrm{M}$. The following PCR amplification protocol was used: $4 \mathrm{~min}$ at $94^{\circ} \mathrm{C} ; 35$ cycles consisting of $1 \mathrm{~min}$ at $94^{\circ} \mathrm{C}$, $1 \mathrm{~min}$ at $51^{\circ} \mathrm{C}$, and $2 \mathrm{~min}$ at $74^{\circ} \mathrm{C}$; and finally elongation for $5 \mathrm{~min}$ at $74^{\circ} \mathrm{C}$. The amplification products were electrophoresed in a $0.8 \%$ agarose gel and stained with ethidium bromide (42).

Bands containing the amplified 16S rDNA were excised from the gel and purified by using a SpinBind DNA recovery system (FMC BioProducts, Rockland, Maine). The purified DNA was restricted with Sall and HindIIl and ligated into similarly restricted Genescribe-Z vectors pTZ18R and pTZ19R (United States Biochemical Corp.). E. coli $\mathrm{DH} 5 \alpha \mathrm{F}^{\prime}$ was used as the host strain. Transformations were performed by the method of Chung et al. (6), and ampicillin resistance was selected for on Luria agar plates containing $20 \mu \mathrm{g}$ of X-Gal 
(5-bromo-4-chloro-3-indolyl- $\beta$-D-galactoside) per $\mathrm{ml}$ and $5 \mu \mathrm{g}$ of IPTG (isopropyl- $\beta$-D-thiogalactoside) per ml. Plasmid DNAs isolated from white colonies were checked by performing a restriction enzyme analysis by standard procedures (42). The following strategy was used to decrease the possibility of sequencing a clone containing a Taq-induced artifact. For each strand of each $16 \mathrm{~S}$ rRNA gene sequenced, 10 to 20 different clones were isolated. Single-stranded DNA was prepared from each of the clones, and equal amounts of the resulting single-stranded DNAs were pooled and used for sequencing. Single-stranded DNA was prepared as recommended by the plasmid manufacturer (United States Biochemical Corp.), except that phage-infected cells were grown for no more than $8 \mathrm{~h}$ rather than 14 to $18 \mathrm{~h}$ prior to harvesting.

Sequencing. Single-stranded templates were sequenced by the dideoxy chain termination method of Sanger et al. (43) by using a Sequenase version 2.0 DNA sequencing kit (United States Biochemical Corp.). The DNA polymerase was prediluted in glycerol enzyme dilution buffer containing $\mathrm{PP}_{i}$; annealing and labeling with $\alpha-S^{35}$-labeled dATP (Amersham Corp., Arlington Heights, III.) were performed as recommended by the manufacturer. Termination reactions were performed at $60^{\circ} \mathrm{C}$ for $5 \mathrm{~min}$. In some cases, the reactions were performed with dITP as well as dGTP to relieve compression artifacts associated with G-C-rich regions of sequence. Sequencing gels were prepared and electrophoresed with glycerol-tolerant gel buffer (United States Biochemical Corp.). Standard methods were used for electrophoresis and autoradiography (42)

Sequence alignment and analyses. Sequences were aligned with the mos similar sequences obtained from the GenBank/EMBL and Ribosomal Database Project databases $(11,31)$. Sequences were retrieved from the Ribosomal Database Project in an aligned format. The sequences generated in this study were aligned manually by using conserved primary and secondary structural features, and regions where the alignment was ambiguous were not included in the phylogenetic analysis.

The results of the distance matrix and parsimony methods used for phylogenetic inference were compared in order to ensure consistency in tree topology. Pairwise similarity values were determined and were converted to evolutionary distances by using the Jukes-Cantor (27), Kimura two-parameter (28), and maximum-likelihood (13) models of nucleotide substitution offered in the DNADIST program in PHYLIP version 3.5c (15). The transition-to-transversion ratio used was set at $2: 1$ when permitted by the program employed. Evolutionary distances were converted into dendrograms by the algorithm of Fitch and Margoliash (17) using the FITCH program in PHYLIP (15). The input order of species was randomized by using the " $\mathrm{J}$ (Jumble)" option, and 20 different input orders were analyzed. The "G (Global)" branch-swapping option was also used, and this option allowed us to reconsider the position of every species after the last species was added to the tree. Output data from the FITCH programs were converted into unrooted trees by using the DRAWTREE program in PHYLIP version 3.5c (15). The trees constructed from the distance matrix data were compared with the trees obtained by a parsimony method based on the Fitch model of nucleotide substitution (16) available in PAUP version 3.0s (47). A search for optimal trees was performed by using the branch-and-bound algorithm and heuristic methods in which we used stepwise addition and tree bisection and reconnection branch swapping (48); the trees obtained with the different search methods were compared. The statistical validity of the trees was investigated by the bootstrap method of numerical resampling (14) by using the SEQBOOT program in PHYLIP version $3.5 \mathrm{c}$ (15) and the bootstrap option in PAUP version $3.0 \mathrm{~s}$ (47) In both cases, 200 bootstrap resamplings were performed. In addition to the Leptothrix and Sphaerotilus sequences determined in this study, sequences of representative organisms belonging to the $\beta$ and $\gamma$ subgroups of the Proteobacteria in the databases $(11,31)$ were also included in the phylogenetic analysis.

Nucleotide sequence accession numbers. The sequences determined in this study have been deposited in the Genome Sequence DataBase (GSDB) at Los Alamos National Laboratory (formerly GenBank) under the following accession numbers: " $L$. discophora" SP-6, L33974; " $L$. discophora" SS-1, L33975; L. cholodnii LMG 7171, L33979; Leptothrix sp. strain NC-1, L33981; and S. natans ATCC 15291, ATCC 29329, ATCC 29330, and ATCC $13338^{\mathrm{T}}$ (T = type strain), L33976, L33977, L33978, and L33980, respectively.

\section{RESULTS AND DISCUSSION}

Morphological comparison. Phase-contrast photomicrographs of the four Leptothrix and four Sphaerotilus strains used in this study are shown in Fig. 1. No sheath was detected by phase-contrast microscopy on cells of " $L$. discophora" SS-1 (Fig. 1a), L. cholodnii (Fig. 1b), and Leptothrix sp. strain NC-1 (Fig. 1c); however, phase-dense or refractile manganese oxide aggregates were produced extracellularly when cells were grown in PTYP medium containing $\mathrm{Mn}^{2+}$ (Fig. 1a through c). A lack of sheath formation in cultures of " $L$. discophora" SS-1 (1) and other Leptothrix strains, including L. cholodnii (34), has been reported previously. We found that the formation of smooth colonies by these strains on PTYP agar was correlated with a lack of sheath formation (unpublished data). In contrast, as described previously $(1,12)$, the " $L$. discophora" SP-6 culture which we studied contained individual unsheathed cells, as well as filaments of cells inside sheaths encrusted with manganese oxides (Fig. 1d, arrow), and this organism produced rough colonies with filamentous edges on PTYP agar. Strain SP-6 cultures characteristically produce rough colonies and exhibit a sheathed phenotype in PTYP media, but they occasionally contain sheathless variants that produce smooth colonies $(1,12)$.

Cellular diameter is a major criterion for distinguishing Leptothrix species. In this study, cells of $L$. cholodnii (Fig. 1b) growing in PTYP medium ranged from 0.70 to $0.75 \mu \mathrm{m}$ in diameter, which is consistent with the lower end of the cell diameter range reported previously for this species $(0.7$ to 1.3 $\mu \mathrm{m})$ (34). Cells of "L. discophora" SS-1 (Fig. 1a) and SP-6 (Fig. 1b) grown under the same conditions ranged from 0.70 to 0.85 $\mu \mathrm{m}$ in diameter, as reported previously $(1,12)$. Cells of Leptothrix sp. strain NC-1 (Fig. 1c) ranged from 0.85 to $1.0 \mu \mathrm{m}$ in diameter. Phase-dense granules containing poly- $\beta$-hydroxybutyrate $(1,34)$ were visible inside the cells of all four Leptothrix spp. strains (Fig. 1a through d).

No phase-contrast microscopy-detectable sheath was observed in any of the $S$. natans strains growing in the liquid CGYA medium recommended by the American Type Culture Collection or in a standard peptone-glucose medium (35). No manganese oxide was deposited in media containing $\mathrm{Mn}^{2+}$. Like the sheathless Leptothrix strains described above, three of the $S$. natans strains (strains ATCC $13338^{\mathrm{T}}$, ATCC 29329, and ATCC 29330) produced smooth colonies with uniform edges on both recommended media. The formation of smooth colonies was correlated with the occurrence of sheathless cells in liquid media, as determined by phase-contrast microscopy (Fig. If through h). Only $S$. natans ATCC 15291 (Fig. 1f) did not follow this pattern. This organism produced rough, filamentous colonies despite the lack of a phase-contrast microscopy-detectable sheath in liquid media. The loss of sheath formation in $S$. natans cultures has been described previously (35).

Cellular clumping was a notable macroscopic feature observed in three of the four $S$. natans strains when they were grown with decreased aeration in liquid cultures. All of the Sphaerotilus strains grew more slowly and had lower final cell yields in the peptone-glucose medium than in CGYA medium. Cultures of type strain ATCC 13338 (Fig. 1e) did not exhibit the clumping phenomenon in either medium. On the other hand, these cultures did contain a large number of branched cells (Fig. 1e), especially in the late log phase of growth on CGYA medium. Cellular branching also was observed in CGYA medium cultures of strain ATCC 29329 (Fig. 1h). Both strain ATCC $13338^{\mathrm{T}}$ and strain ATCC 29329 exhibited less pronounced cellular branching in the peptone-glucose medium. To our knowledge, true cellular branching (as shown in Fig. 1e and $\mathrm{h}$ ) has not been observed previously in $S$. natans cultures, although false branching has been described (35).

The range of cell diameters for $S$. natans ATCC $13338^{\mathrm{T}}$ (Fig. 1e) and ATCC 29329 (Fig. 1h) growing in CGYA medium was approximately 1.5 to $1.7 \mu \mathrm{m}$; for strain ATCC 29330 (Fig. 1g) the range of cell diameters was 1.3 to $1.5 \mu \mathrm{m}$; and for strain ATCC 15291 (Fig. 1f) the range of cell diameters was 1.8 to 2.0 $\mu \mathrm{m}$. These cellular diameter ranges are consistent with the values reported previously (35). As in the Leptothrix cultures, phase-dense poly- $\beta$-hydroxybutyrate granules were observed inside cells in the $S$. natans cultures (Fig. 1e through h).

Genomic fingerprinting. Genomic fingerprints were generated via PCR using primers based on ERIC sequences (26). 

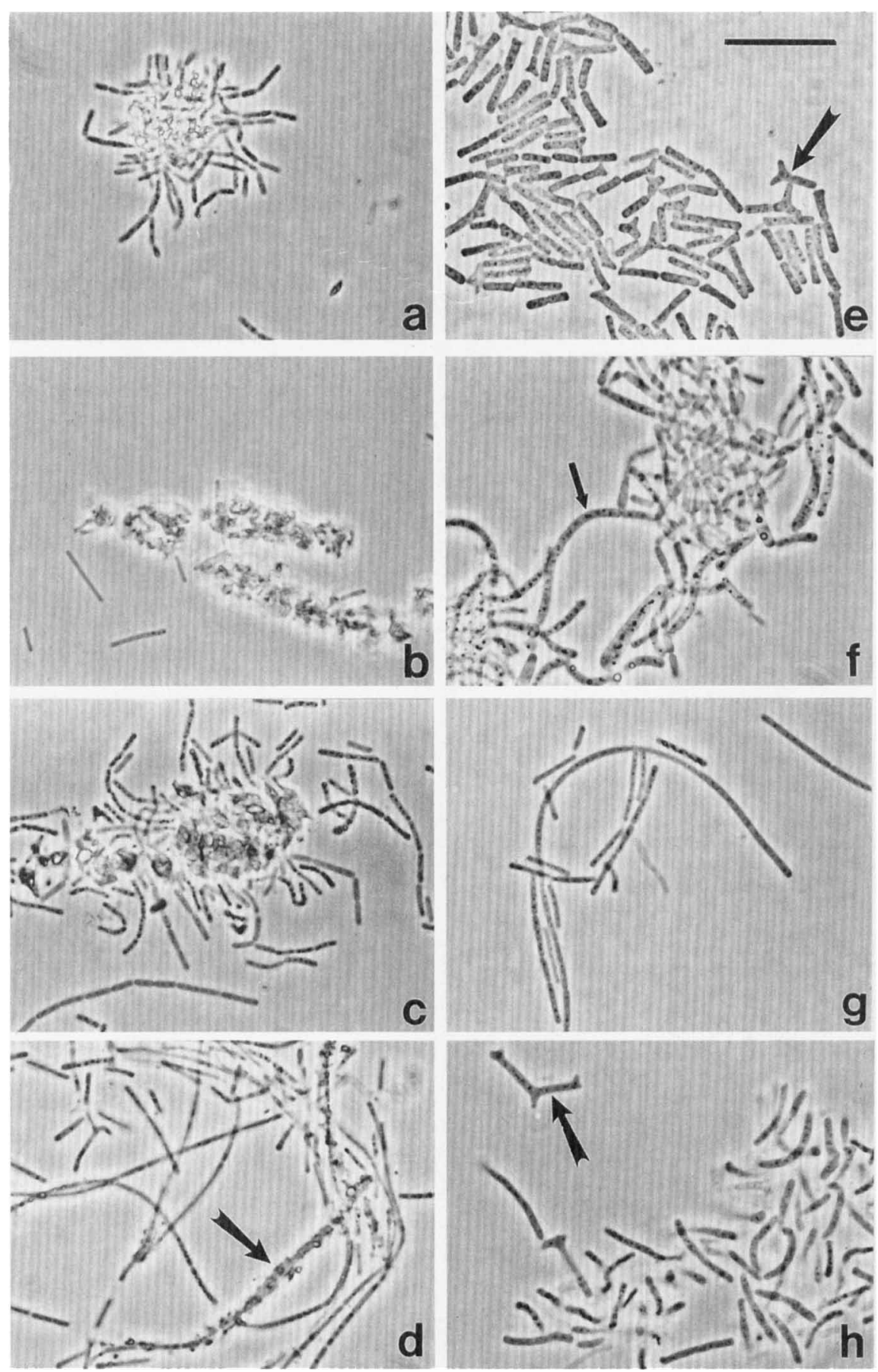

FIG. 1. Phase-contrast photomicrographs of strains belonging to the Leptothrix-Sphaerotilus group. (a) "L. discophora" SS-1. (b) L. cholodnii LMG 7171. (c) Leptothrix sp. strain NC-1. (d) "L. discophora" SP-6. The arrow indicates a manganese oxide-encrusted sheath. (e) $S$. natans ATCC $13338^{\mathrm{T}}$. (f) $S$. natans ATCC 15291 . (g) S. natans ATCC 29330. (h) S. natans ATCC 29329. The arrows in panels e and h indicate branched cells. Phase-dense poly- $\beta$-hydroxybutyrate granules are visible in all micrographs and are indicated by the arrow in panel $\mathrm{f}$. Bar $=15 \mu \mathrm{m}$. See text for details.

This technique was useful for distinguishing all of the strains included in this study (Fig. 2). The fingerprints obtained were reproducible and independent of whether purified DNA or whole cells were used as the template for the PCR (data not shown); similar results regarding template preparation were reported recently by Louws et al. (32). Among the Leptothrix strains, the most divergent band pattern was observed in Leptothrix sp. strain NC-1 (Fig. 2A, lanes 3 and 4) since this pattern did not appear to share any common bands with the patterns of the other Leptothrix strains. All of the other Leptothrix strains examined in this study produced a strong band at approximately 480 bp (Fig. 2A, lanes 1 through 2 and 5 through 8 ), and the intensity of this band was significantly greater in " $L$. discophora" SS-1 than in the other strains (Fig. 2A, lanes 1 and 2). The differences in intensity could have been due to preferential amplification of this fragment in strain SS-1 or to the presence 


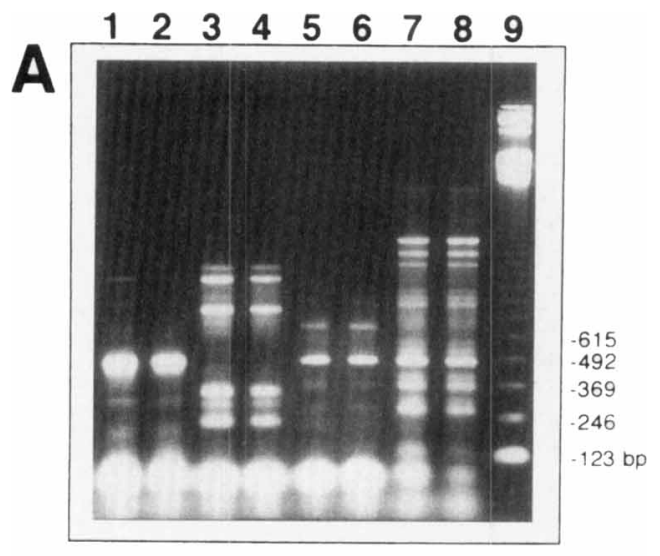

$\begin{array}{lllllllll}1 & 2 & 3 & 4 & 5 & 6 & 7 & 8 & 9\end{array}$

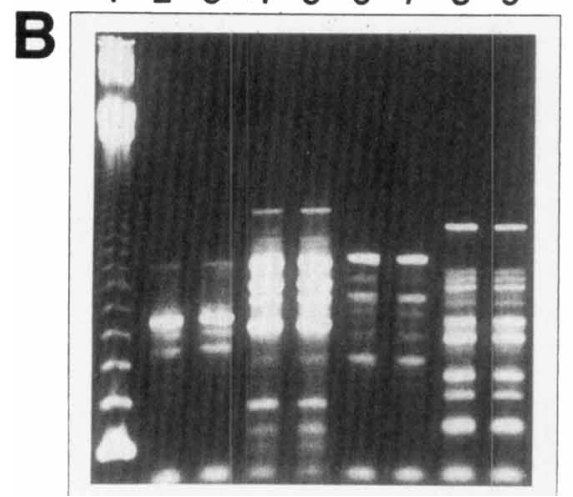

FIG. 2. ERIC PCR fingerprint patterns obtained by using whole cells of strains belonging to the Leptothrix-Sphaerotilus group. (A) Lanes 1 and 2, " $L$. discophora" SS-1; lanes 3 and 4, Leptothrix sp. strain NC-1; lanes 5 and $6, L$. cholodnii LMG 7171; lanes 7 and 8, "L. discophora" SP-6; lane 9, $3 \mu \mathrm{g}$ of a 123-bp DNA ladder (Gibco BRL Life Technologies, Gaithersburg, Md.). (B) Lane 1, 3 $\mu \mathrm{g}$ of a 123-bp DNA ladder (Gibco BRL Life Technologies); lanes 2 and 3, S. natans ATCC 15291; lanes 4 and 5, S. natans ATCC 13338 ${ }^{\mathrm{T}}$; lanes 6 and $7, S$. natans ATCC 29330; lanes 8 and 9, S. natans ATCC 29329. See text for details.

of other fragments of equal length which comigrated during electrophoresis. In addition to this band, $L$. cholodnii and " $L$. discophora" SP-6 had two other bands in common (at approximately 260 and $350 \mathrm{bp}$ ) (Fig. 2A, lanes 5 through 8 ); however, these bands were consistently of brighter intensity in " $L$. discophora" SP-6 than in L. cholodnii. The fingerprint profiles produced by the $S$. natans strains (Fig. 2B) were clearly distinct from those produced by the Leptothrix strains (Fig. 2A). Among the $S$. natans strains, the profiles produced by strains ATCC $13338^{\mathrm{T}}$ (Fig. 2b, lanes 4 and 5) and ATCC 29330 (Fig. $2 \mathrm{~b}$, lanes 6 and 7) had the greatest number of bands in common. It is worth noting that even though the $16 \mathrm{~S}$ rDNA sequence of $S$. natans ATCC $13338^{\mathrm{T}}$ was identical to that of $S$. natans ATCC 15291 in the 300-nucleotide region examined (GSDB accession numbers L33980 and L33976, respectively), the fingerprint profiles of these organisms were different.

Comparison of $16 \mathrm{~S}$ rDNA sequences. The $16 \mathrm{~S}$ rDNA sequence of " $L$. discophora" SS-1 obtained in this study (GSDB accession number $\mathrm{L} 33975$ ) differed at 8 of 1,354 positions from the 16S rDNA sequence of the same gene obtained by Corstjens and Muyzer (8). The same strain (strain SS-1 [ATCC 43182], which originally was isolated by Ghiorse and Chapnick [21]) was examined in both studies; therefore, we expected the $16 \mathrm{~S}$ rDNA sequences to be identical. Differences between the two sequences consistently occurred in G-C-rich stretches at positions $359,383,912,914,915,1138,1397$, and 1398 in our alignment scheme. Three of the differences were the result of an exchange of a guanine for a cytosine, while five of the differences resulted from omission of a guanine or cytosine in the sequence of Corstjens and Muyzer $(8,9)$. The acceptance of $16 \mathrm{~S}$ rRNAs as molecular chronometers is based on (among other things) the functional constancy of these molecules, which dictates slow rates of change that reflect evolutionary distances. Therefore, it is unlikely that the differences between the sequences which we observed were due to strain differences resulting from mutational events. Rather, we believe that the lack of sequence agreement can most likely be attributed to difficulties in reading the sequence caused by the high $\mathrm{G}+\mathrm{C}$ content $(71 \mathrm{~mol} \%)$ of the organism (12). In the sequencing procedure described by Corstjens and Muyzer $(8,9)$, G-C-rich regions were prone to compression artifacts which made sequences in these regions difficult to read (7a). The methods that we used for sequencing resulted in an easily read sequence even in G-C-rich regions. Thus, we believe that our sequence was more accurate than the previously described sequence.

When we compared the partial 16S rDNA sequence determined in this study for S. natans ATCC 29329 (GSDB accession number L33977) with the complete sequence determined by Corstjens (9) and Corstjens and Muyzer (8) for the same strain, we found two differences in the 250 -base region where the sequences overlapped. Although the strains were identified as the same organism, they were obtained from different culture collections. However, for the reasons discussed above, it is impossible to rule out the possibility that there are sequence errors in the sequence described by Corstjens (9) and Corstjens and Muyzer (8).

Construction of phylogenetic trees. Three models of nucleotide substitution (the Jukes-Cantor [27], Kimura two-parameter [28], and maximum-likelihood [13] models) were used to construct evolutionary distance matrixes in order to ensure consistent tree topology based on 16S rDNA sequence information. Evolutionary distance values were calculated by using complete (Table 2) and partial sequences (Table 3 ). The distance values calculated by using the Jukes-Cantor model were consistently less (by 1.5 to $5.5 \%$ ) than the values calculated by using the maximum-likelihood or Kimura two-parameter model. The greatest differences between the results obtained with these models occurred when we compared the greatest evolutionary distances. Regardless of whether partial or complete sequences were analyzed, the evolutionary distances generated by the Kimura two-parameter and maximum-likelihood models typically differed by less than $0.1 \%$. Because of this similarity, the results of the analyses in which the Kimura two-parameter model were used are not shown in Tables 2 and 3.

When the distance values for the complete sequences and the partial sequences (Tables 2 and 3 , respectively) were used to generate dendrograms, the topologies (for a given data set) were virtually identical regardless of which of the three methods was used to calculate the distances (data not shown). As expected, the greater distance values calculated with the maximum-likelihood and Kimura two-parameter models led to longer branch lengths on the inferred trees. Trees generated from the maximum-likelihood distance values estimated by using the complete and partial $16 \mathrm{~S}$ rDNA sequence data (Tables 2 and 3, respectively) are shown in Fig. 3 and 4, respectively.

For both the partial and the complete sequences, parsimony analysis in which we used heuristic searches (by either the tree bisection and reconnection method or the stepwise addition 


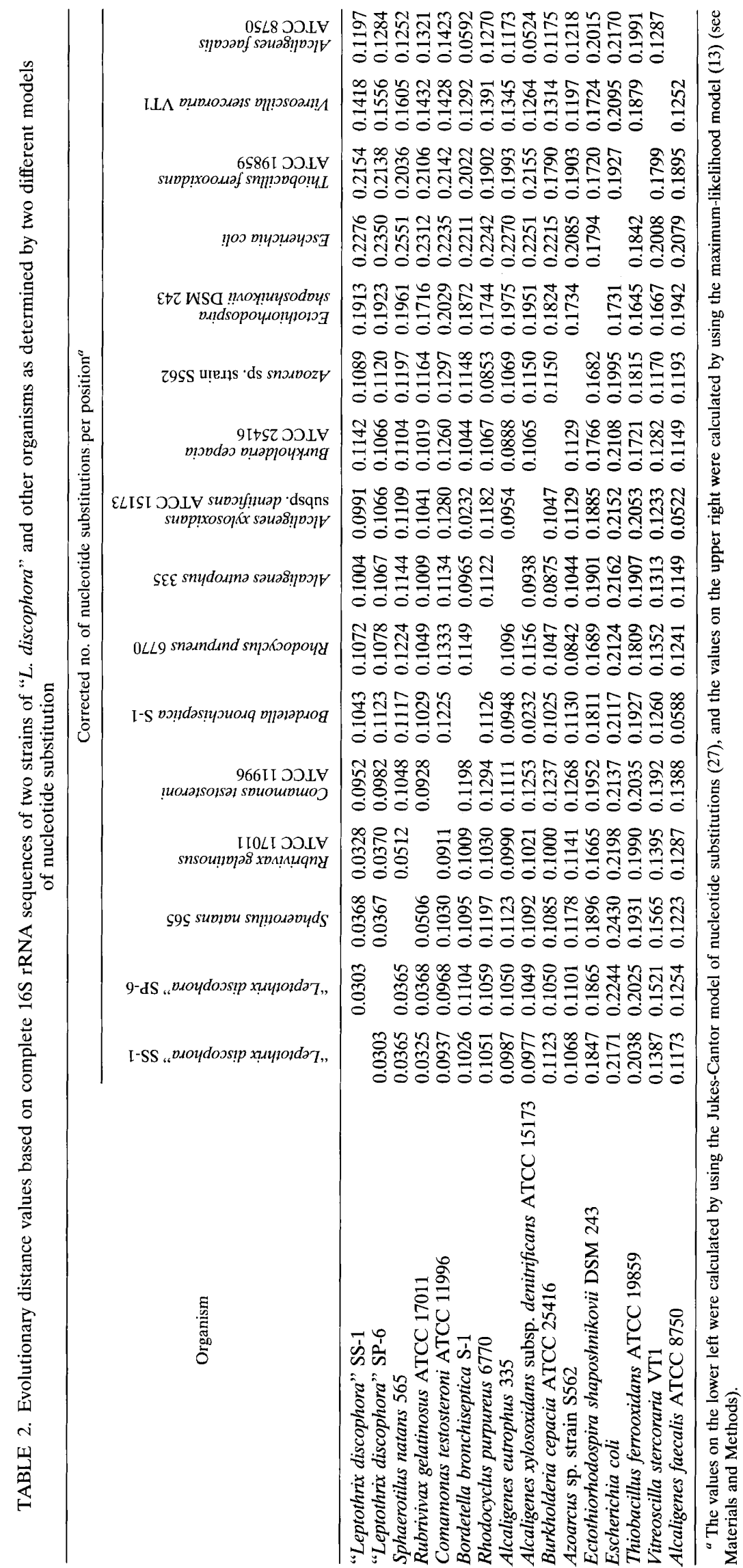


TABLE 3. Evolutionary distance values based on partial 16S rRNA sequences of Leptothrix and Sphaerotilus strains and other organisms as determined by two different models of nucleotide substitution

\begin{tabular}{|c|c|c|c|c|c|c|c|c|c|c|c|c|c|}
\hline \multirow[b]{2}{*}{ Organism } & \multicolumn{13}{|c|}{ Corrected no. of nucleotide substitutions per position ${ }^{a}$} \\
\hline & 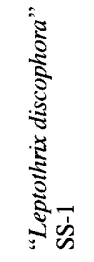 & 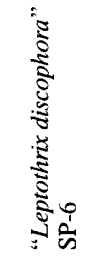 & 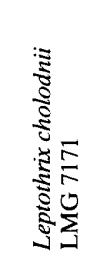 & 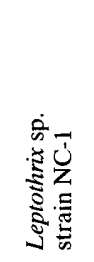 & 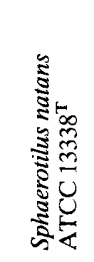 & 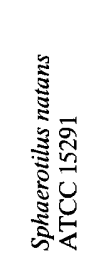 & 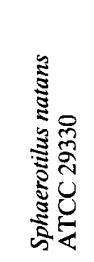 & 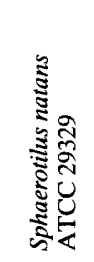 & 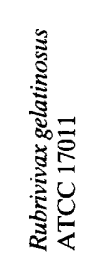 & 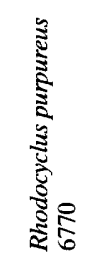 & 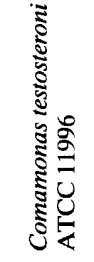 & 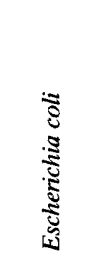 & 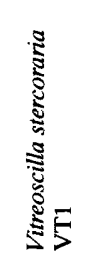 \\
\hline "Leptothrix discophora" SS-1 & & 0.0781 & 0.0822 & 0.0861 & & 0.0865 & & 0.0589 & & 0.2282 & 0.1727 & & 0.180 \\
\hline “Leptothrix discophora" SP-6 & 0.0770 & & 0.0035 & 0.0070 & 0.1015 & 0.1015 & 0.0976 & 0.0812 & 0.0850 & 0.2388 & 0.1960 & & 0.24 \\
\hline Leptothrix cholodnii LMG 7171 & 0.0809 & 0.0035 & & 0.0035 & 0.1058 & 0.1058 & 0.1018 & 0.0853 & 0.0808 & 0.2333 & 0.1910 & 0.3930 & 0.2452 \\
\hline Leptothrix sp. strain NC-1 & 0.0848 & 0.0070 & 0.0035 & & 0.1017 & 0.1017 & 0.0978 & 0.0814 & 0.0847 & 0.2 & 0.1864 & & 0.2500 \\
\hline Sphaerotilus natans ATCC $13338^{\mathrm{T}}$ & 0.0854 & 0.1013 & 0.1053 & 0.1013 & & 0.0000 & 0.0322 & 0.0322 & 0.1104 & 0.2 & 0.1893 & 0.3765 & 0.2136 \\
\hline Sphaerotilus natans ATCC 15291 & 0.0854 & 0.1013 & 0.1053 & 0.1013 & 0.0000 & 0.0322 & 0.0322 & 0.1104 & 0.2054 & 0.1893 & 0.3765 & 0.2136 & \\
\hline Sphaerotilus natans ATCC 29330 & & 0.0973 & 0.1013 & 0.0973 & 0.0323 & 0.0323 & & 0.0213 & 0.1063 & & 0.1803 & 0.3615 & 0.2311 \\
\hline Sphaer & 0579 & 0.0809 & 0.0848 & 0.0809 & 0.0323 & 0.0323 & 0.0214 & & 0.1188 & & 0.1986 & 0.3881 & 0.2477 \\
\hline Rubrivivax gelatinosus ATCC 17011 & 0.1082 & 0.0836 & 0.0796 & 0.0836 & 0.1082 & 0.1082 & 0.1040 & 0.1165 & & 0.1880 & 0.1321 & 0.3354 & 0.1788 \\
\hline Rhodocyclus purpureus 6770 & 0.2155 & 0.2297 & 0.2249 & 0.2297 & 0.1969 & 0.1969 & 0.1877 & 0.2061 & 0.1832 & & 0.1862 & 0.3096 & 0.1845 \\
\hline Comamonas testosteroni ATCC 11996 & & 0.1923 & & 0.1832 & 0.1832 & 0.1832 & 0.1742 & 0.1923 & 0.1304 & 0.1796 & & 0.2718 & 0.1501 \\
\hline Escherichia coli & 0.2975 & 0.3629 & & 0.3744 & 0.3460 & 0.3460 & 0.3321 & 0.3573 & 0.3094 & 0.2824 & 0.2576 & & 0.2677 \\
\hline Vitreoscilla stercoraria VT1 & 0.1763 & 0.2375 & 0.2375 & 0.2424 & 0.2040 & 0.2040 & 0.2211 & 0.2375 & 0.1725 & 0.1780 & 0.1474 & 0.2544 & \\
\hline
\end{tabular}

${ }^{a}$ The values on the lower left were calculated by using the Jukes-Cantor model for nucleotide substitution (27), and the values on the upper right were calculated by using the maximum-likelihood model (13) (see Materials and Methods).

method) often resulted in the generation of two most parsimonious trees. However, when the branch-and-bound search strategy was used, only one tree was generated for a given data set. Invariably, this tree was identical to one of the trees obtained by heuristic search methods. Although they are more computer intensive, exact algorithms (such as the branch-andbound method) are preferred over heuristic search methods because they guarantee optimality $(47,48)$.

Comparisons of phylogenetic trees. When we compared trees produced by the parsimony method with trees produced by the distance matrix methods, we observed only minor differences regardless of whether complete or partial sequences were analyzed. Because of the similarity, the trees produced by the parsimony method are not included in this paper.

Trees derived from complete sequences revealed that " $L$. discophora" SS-1 and SP-6 grouped with S. natans, Rubrivivax gelatinosus, and Pseudomonas testosteroni in the Rubrivivax subgroup of the $\beta$ group of the Proteobacteria as defined by the phylogenetically ordered list in the Ribosomal Database Project database, version 4.0 (31). Although the parsimony tree indicated that strain SP-6 is slightly more closely related to $S$. natans than is strain SS-1, the distance matrix tree (Fig. 3) showed that these two Leptothrix strains are approximately equidistant from $S$. natans. The results of bootstrap resampling of the data set generally supported the tree topology shown in Fig. 3 (see branch node frequencies in Fig. 3). The bootstrap analysis revealed high levels of confidence for the placement of members of the $\gamma$ group of the Proteobacteria, members of the Rubrivivax subdivision of the $\beta$ group of the Proteobacteria, and members of the Bordetella subgroup of the $\beta$ group of the Proteobacteria (containing Bordetella bronchiseptica, Alcaligenes xylosoxidans, and Alcaligenes faecalis). The levels of confidence were lower for the placement of " $L$. discophora" SP-6 with respect to $S$. natans and for the positions of Rhodocyclus purpureus and Azoarcus sp.

The estimated evolutionary distances generated from comparisons of complete sequences (Table 2) were always much smaller than the distances generated from comparisons of partial sequences (Table 3), thus showing that the region chosen for partial sequencing was more variable than was the $16 \mathrm{~S}$ rRNA molecule as a whole. The differences were more pronounced in the Leptothrix and Sphaerotilus sequences than in the sequences of the other members of the $\beta$ group of the Proteobacteria examined in this study; this reflects the somewhat fortuitous reasons for choosing the region used for partial sequencing. Complete sequencing of the 16S rRNA genes of "L. discophora" SP-6 and SS-1 revealed sequences in the V1

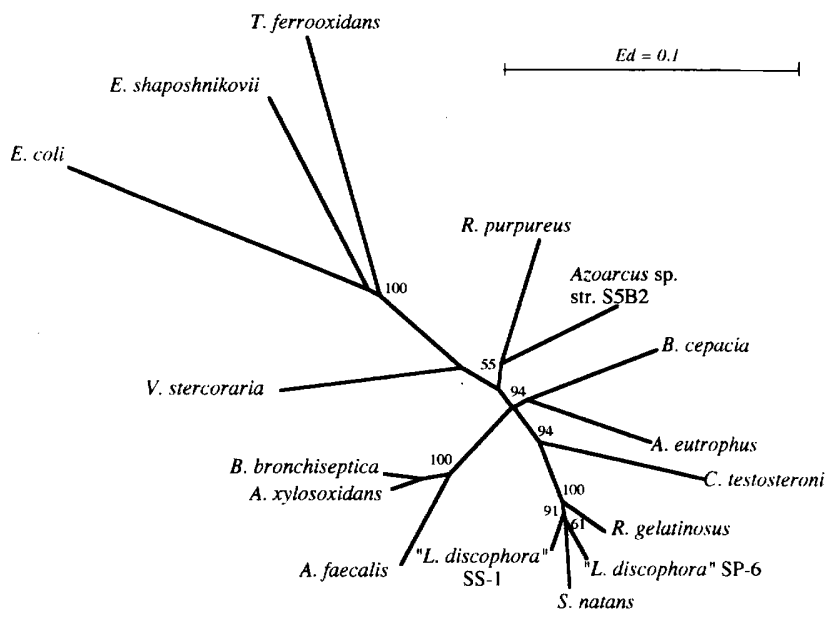

FIG. 3. Phylogenetic tree based on complete 16S rRNA gene sequences determined in this study for " $L$. discophora" SS-1 and SP-6 and complete $16 \mathrm{~S}$ rRNA gene sequences of other members of the $\beta$ and $\gamma$ groups of the Proteobacteria. The tree was constructed by using evolutionary distance estimates based on the maximum-likelihood model of nucleotide substitution (13). Each value at a branch point indicates the percentage of 200 bootstrap samples which yielded the branching pattern beyond the node. See text for details, and see Table 2 for strains used in this analysis. 


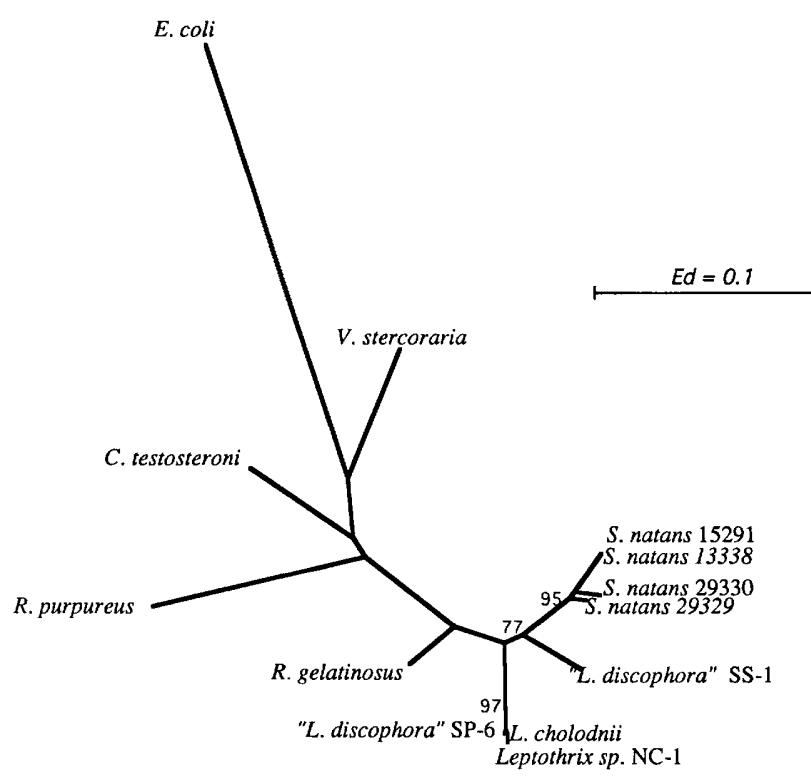

FIG. 4. Phylogenetic tree based on partial sequences of 16S rRNA genes corresponding to approximately $E$. coli positions 8 to 304 . The sequences of " $L$. discophora" SS-1 and SP-6, L. cholodnii LMG 7171, Leptothrix sp. strain NC-1, and $S$. natans ATCC $13338^{\mathrm{T}}$, ATCC 15291, ATCC 29329, and ATCC 29330 were determined in this study, and these sequences were compared with the sequences of other members of the $\beta$ group of the Proteobacteria. E. coli was used as an outgroup. The tree was constructed by using evolutionary distance estimates based on the maximum-likelihood model of nucleotide substitution (13). Each values at a branch point indicates the percentage of 200 bootstrap samples which yielded the branching pattern beyond the node. See text for details, and see Table 3 for the strains used in this analysis.

and V2 hypervariable regions which had potential for distinguishing Leptothrix spp. from other members of the $\beta$ group of the Proteobacteria. In order to confirm that this region was useful for generating phylogenies, we compared the estimated phylogenies based on complete and partial sequences of this region for several members of the $\beta$ group of the Proteobacteria, including the two strains of " $L$. discophora" included in this study. The tree topologies were nearly identical whether the partial or complete sequences were used (data not shown).

The distance estimates generated by using partial sequences (Table 3 ) showed that "L. discophora" SS-1 was approximately equidistant from the Leptothrix lineage (containing " $L$. discophora" SP-6, L. cholodnii LMG 7171, and Leptothrix sp. strain NC-1) and from each of the three of the $S$. natans strains (strains ATCC $13338^{\mathrm{T}}$, ATCC 15291, and ATCC 29330). However, strain SS-1 was more closely related to $S$. natans ATCC 29329 than to "L. discophora" SP-6. A similar partitioning of Leptothrix strains was described by Willems et al. (53), who compared the electrophoretic patterns of whole-cell protein extracts obtained from five strains of " $L$. discophora" (including strains SS-1 and SP-6) and one strain of $L$. cholodnii (strain LMG 7171). In that study " $L$. discophora" SS-1 was found to have the most aberrant pattern of all of the "L. discophora" strains. In addition, Willems et al. found that the protein patterns of "L. discophora" and $L$. cholodnii LMG 7171 were similar. In our study the distance values obtained from the comparisons of the complete sequences of strains SS-1 and SP-6 (Table 2) showed that these strains were approximately equidistant from $S$. natans, while strain SS-1 was slightly closer to Rubrivivax gelatinosus than was strain SP-6. In contrast, the distance estimates based on partial sequences (Table 3) implied that strain SS-1 was further from Rubrivivax gelatinosus than was strain SP-6 and closer to $S$. natans ATCC 29329 than was strain SP-6. This analysis also revealed that strain SP-6 was approximately equidistant from $S$. natans ATCC 29329 and Rubrivivax gelatinosus.

As mentioned above, the complete $S$, natans sequence determined by Corstjens (9) and Corstjens and Muyzer (8) was not identical to the $S$. natans ATCC 29329 sequence in the partial sequence region that we determined, even though the organisms used were supposedly the same. Thus, the differences in evolutionary distance estimates based on complete and partial sequences noted above may have been due to the sequence discrepancies in this region. In DNA-rRNA hybridization experiments performed with $23 \mathrm{~S}$ rRNA from " $L$. discophora" SP-6 and DNAs from several members of the $\beta$ group of the Proteobacteria, Willems et al. (53) found that $R$. gelatinosus was a closer relative of strain SP-6 than was $S$. natans ATCC $13338^{\mathrm{T}}$; this finding is consistent with the results shown in Table 3.

When the distance estimates computed by the maximumlikelihood model (Table 3 ) were translated into a phylogenetic tree (Fig. 4), we detected a problem concerning the placement of Comamonas testosteroni. Although this problem did not affect the relative positions of the Leptothrix and Sphaerotilus strains analyzed in this study, the error is worth noting. We expected that $C$. testosteroni, a member of the Rubrivivax subdivision of the $\beta$ group of the Proteobacteria, would cluster closer than it did to the other members of this subdivision $(S$. natans, Leptothrix spp., and Rubrivivax gelatinosus), as was observed in the trees obtained from the parsimony analysis of the partial sequences (data not shown). This discrepancy was most likely due to the fact that the region used for the partial $16 \mathrm{~S}$ rDNA analysis exhibited more variability than the sequence of the entire $16 S$ rDNA molecule.

What clearly stands out in the trees generated by using the partial sequences (Fig. 4) is the existence of two distinct Leptothrix lineages. "L. discophora" SP-6 was found to be more closely related to L. cholodnii LMG 7171 and Leptothrix sp. strain NC-1 than to " $L$. discophora" SS-1. In fact, there was only a one-base difference between " $L$. discophora" SP-6 and L. cholodnii in the 315-bp region that we sequenced (data not shown). Our bootstrap resampling analysis revealed a high degree of confidence for this separation of Leptothrix strains into two groups and for the clustering of the $S$. natans strains in one lineage (see branch node frequencies in Fig. 4). However, the position of " $L$. discophora" SS-1 with respect to the other Leptothrix lineage and to the $S$. natans cluster is less clear (as indicated by the low confidence value, $77 \%$ ).

Conclusions. In this paper we provide new information concerning the phylogeny of the Leptothrix-Sphaerotilus group. In this study we linked traditional descriptive methods of taxonomic analysis with contemporary molecular taxonomic and phylogenetic methods. A major finding of our phylogenetic analyses was the existence of two Leptothrix lineages, one containing " $L$. discophora" SS-1 and the other containing " $L$. discophora" SP-6, L. cholodnii, and previously uncharacterized Leptothrix sp. strain NC-1. The lineage containing strain SS-1 appeared to be slightly more closely related to $S$. natans than to $R$. gelatinosus, while the converse was true for the other lineage. These results also show that " $L$. discophora" SP-6 is more closely related phylogenetically to $L$. cholodnii than to " $L$. discophora" SS-1. These findings indicate that the taxonomy and nomenclature of Leptothrix species need to be revised to more closely reflect these phylogenetic relationships. Although the $S$. natans strains examined in this work differed morphologically and each strain produced different ERIC fingerprints, we found that these strains were closely related to one another 
on the basis of partial sequence analysis results (Table 3 ). In fact, the $S$. natans ATCC $13338^{\mathrm{T}}$ and ATCC 15291 sequences were identical in the 300 -base region examined (data not shown).

An additional benefit of our sequence analysis was the fact that we identified signature sequences in the first two hypervariable regions which had potential for designing Leptothrix and Sphaerotilus genus- and strain-specific probes (44). Recently, we have designed $16 \mathrm{~S}$ rRNA-targeted oligonucleotide probes which have allowed us to discriminate between the genera Sphaerotilus and Leptothrix and to differentiate the two Leptothrix lineages identified in this study (manuscript in preparation). These probes have been successfully used with pure cultures, and they have been shown to discriminate between filamentous bacteria in wetland samples.

We determined that the ERIC PCR technique is useful for distinguishing the closely related strains of Leptothrix spp. and $S$. natans examined in this work, and this finding supplemented the results of previous studies $(10,32,49)$. However, we believe that demonstrating the presence or absence of comigrating bands in different strains is not by itself sufficient to draw conclusions regarding evolutionary relatedness. We agree with the suggestion of Louws et al. (32) that when there are comigrating bands, additional experiments (i.e., analyses to determine complete sequences of the 16S rRNA genes, DNA reassociation experiments, fatty acid profile analyses, and phenotypic tests) should be performed.

The currently accepted taxonomic criteria for differentiating Leptothrix spp. are phenotypic properties (primarily cellular dimensions, sheath morphology, and response to added organic nutrients) (34). Similarly, differentiation of the genera Leptothrix and Sphaerotilus is based on phenotypic properties (flagellar arrangement, sheath morphology, manganese-oxidizing ability, and response to organic nutrients) (35). We confirmed that, as has been found for other bacterial groups, $16 \mathrm{~S}$ rRNA sequence information can be used to distinguish Leptothrix and Sphaerotilus strains. At this time, there is no defined threshold limit of similarity which we can use to define a species or genus (46). It appears that the results of DNA reassociation experiments are the only quantitative way in which a species can be defined at this time $(46,51)$. It has been suggested that when the level of $16 \mathrm{~S}$ rRNA sequence similarity (for the entire sequence) is $97 \%$ or higher, DNA-DNA reassociation experiments should be performed in order to determine the relatedness of the closely related taxa (46). Obviously, we need more genetic and biochemical characteristics to further define the genera Leptothrix and Sphaerotilus and to differentiate Leptothrix species. Ideally, these characteristics would include complete sequences of the $16 \mathrm{~S}$ rDNA, fatty acid profile data, comprehensive DNA-DNA reassociation data, and additional chemotaxonomic data. Such polyphasic taxonomy is the most accurate approach for classifying bacteria in light of the different evolutionary rates of various organisms ( 7 , 37, 46).

In conclusion, we believe that it is important to relate our results to the actual process of identifying new sheathed bacterial isolates obtained from natural samples. Two properties that distinguish the genus Leptothrix from the genus Sphaerotilus are the ability to oxidize $\mathrm{Mn}^{2+}$ and the ability to grow in rich organic media. Furthermore, the habitats from which the organisms are isolated must also be considered. S. natans does not oxidize $\mathrm{Mn}^{2+}$ and typically thrives in water that is rich in organic nutrients (i.e., wastewater), while Leptothrix species oxidize $\mathrm{Mn}^{2+}$ and are usually found in oligotrophic, slowly running, iron- and manganese-rich water. L. cholodnii is an exception; this species is the only cultivated Leptothrix species that responds like $S$. natans by growing rapidly and luxuriantly on rich organic media. The results of our phylogenetic analysis confirmed Pringsheim's contention (40) that the line that differentiates the genera Leptothrix and Sphaerotilus is artificial and tenuous; however, in the absence of additional experimental data (see above) and for the practical reason that important habitat differences do exist, we believe that these two genera should remain separate taxa.

\section{ACKNOWLEDGMENTS}

This work was supported by funds from U.S. Department of Agriculture Hatch Act project 189409 and National Institute of Environmental Health Sciences Superfund Basic Research Education Program grant 05950-03.

We thank Patti Lisk for secretarial assistance, Rhea Garen for expert photographic assistance, and Eugene Madsen for careful review of the manuscript.

\section{REFERENCES}

1. Adams, L. F., and W. C. Ghiorse. 1986. Physiology and ultrastructure of Leptothrix discophora SS-1. Arch. Microbiol. 145:126-135.

2. Ausubel, F. M., R. Brent, R. E. Kingston, D. D. Moore, J. G. Seidman, J. A. Smith, and K. Struhl (ed.). 1992. Short protocols in molecular biology, 2nd ed. John Wiley \& Sons, New York.

3. Avgustin, G., F. Wright, and H. J. Flint. 1994. Genetic diversity and phylogenetic relationships among strains of Prevotella (Bacteroides) numinocola from the rumen. Int. J. Syst. Bacteriol. 44:246-255.

4. Brosius, J., H. L. Palmer, J. P. Kennedy, and H. F. Noller. 1978. Complete nucleotide sequence of a $16 \mathrm{~S}$ ribosomal RNA gene from Escherichia coli. Proc. Natl. Acad. Sci. USA 75:4801-4805.

5. Busse, H. J., T. El-Banna, H. Oyaizu, and G. Auling. 1992. Identification of xenobiotic-degrading isolates from the beta subclass of the Proteobacteria by a polyphasic approach including 16S rRNA partial sequencing. Int. J. Syst. Bacteriol. 42:19-26.

6. Chung, C. T., S. L. Niemal, and R. H. Miller. 1989. One-step transformation of competent Escherichia coli: transformation and storage of bacterial cells in the same solution. Proc. Natl. Acad. Sci. USA 86:2172-2175.

7. Colwell, R. R. 1970. Polyphasic taxonomy of bacteria, p. 421-436. In H. Iizuka and T. Hasegawa (ed.), Culture collections of microorganisms. University of Tokyo Press, Tokyo.

8. Corstjens, P., and G. Muyzer. 1993. Phylogenetic analysis of the metaloxidizing bacteria Leptothrix discophora and Sphaerotilus natans using $16 \mathrm{~S}$ rDNA sequence data. Syst. Appl. Microbiol. 16:219-223.

9. Corstjens, P. L. 1993. Bacterial oxidation of iron and manganese-a molecular biological approach. Ph.D. thesis. Leiden University, Leiden, The Netherlands.

9a.Corstjens, P. L. Personal communication.

10. de Bruijn, F. J. 1992. Use of repetitive (repetitive extragenic palindromic and enterobacterial repetitive intergeneric consensus) sequences and the polymerase chain reaction to fingerprint the genomes of Rhizobium meliloti isolates and other soil bacteria. Appl. Environ. Microbiol. 58:2180-2187.

11. Devereux, J. P., P. Haeberli, and O. Smithies. 1984. A comprehensive set of sequence analysis programs for the VAX. Nucleic Acids Res. 12:387-395.

12. Emerson, D., and W. C. Ghiorse. 1992. Isolation, cultural maintenance, and taxonomy of a sheath-forming strain of Leptothrix discophora and characterization of manganese-oxidizing activity associated with the sheath. Appl. Environ. Microbiol. 58:4001-4010.

13. Felsenstein, J. 1981. Evolutionary trees from DNA sequences: a maximum likelihood approach. J. Mol. Evol. 17:368-376.

14. Felsenstein, J. 1985. Confidence limits on phylogenies: an approach using the bootstrap. Evolution 39:783-791.

15. Felsenstein, J. 1993. PHYLIP (phylogenetic inference package), version 3.5c. Department of Genetics, University of Washington, Seattle.

16. Fitch, W. M. 1971. Toward defining the course of evolution: minimal change for a specific tree topology. Syst. Zool. 20:406-416.

17. Fitch, W. M., and E. Margoliash. 1967. Construction of phylogenetic trees. Science 155:279-284.

18. Gherna, R., and P. Pienta (ed.). 1992. American Type Culture Collection catalogue of bacteria and bacteriophages, 18th ed. American Type Culture Collection, Rockville, Md.

19. Gherna, R., and C. R. Woese. 1992. A partial phylogenetic analysis of the "flavobacter-bacteroides" phylum: basis for taxonomic reconstructuring. Syst. Appl. Microbiol. 15:513-521.

20. Ghiorse, W. C. 1984. Biology of iron- and manganese-depositing bacteria. Annu. Rev. Microbiol. 38:515-550.

21. Ghiorse, W. C., and S. D. Chapnick. 1983. Metal-depositing bacteria and the 
distribution of manganese and iron in swamp waters. Environmental biogeochemistry. Ecol. Bull. (Stockholm) 35:367-376.

22. Ghiorse, W. C., and H. L. Ehrlich. 1992. Microbial biomineralization of iron and manganese, p. 75-101. In R. W. Fitzpatrick and H. C. W. Skinner (ed.), Biomineralization processes of iron and manganese: modern and ancient environments. Catena Verlag, Cremlingen-Destedt, Germany.

22a.Herrick, J. B. Personal communication.

23. Herrick, J. B., E. L. Madsen, C. A. Batt, and W. C. Ghiorse. 1993. Polymerase chain reaction amplification of naphthalene-catabolic and 16S rRNA gene sequences from indigenous sediment bacteria. Appl. Environ. Microbiol. 59:687-694.

24. Hillis, D. M., J. J. Bull, M. R. White, and I. J. Molineux. 1992. Experimental phylogenetics: generation of a known phylogeny. Science 255:589-592.

25. Hillis, D. M., J. P. Huelsenbeck, and C. W. Cunningham. 1994. Application and accuracy of molecular phylogenies. Science 264:671-677.

26. Hulton, C. S. J., C. F. Higgins, and P. M. Sharp. 1991. ERIC sequences: a novel family of repetitive elements in the genomes of Escherichia coli, Salmonella typhimurium and other enterobacteria. Mol. Microbiol. 5:825-834.

27. Jukes, T. H., and C. R. Cantor. 1969. Evolution of protein molecules, p. 21-132. In H. N. Munro (ed.), Mammalian protein metabolism. Academic Press, New York.

28. Kimura, M. 1980. A simple method for estimating evolutionary rates of base substitutions through comparative studies of nucleotide sequences. J. Mol. Evol. 16:111-120.

29. Lane, D. J., A. P. Harrison, Jr., D. Stahl, B. Pace, S. J. Giovannoni, G. J. Olsen, and N. R. Pace. 1992. Evolutionary relationships among sulfur- and iron-oxidizing eubacteria. J. Bacteriol. 174:269-278.

30. Lane, D. J., B. Pace, G. J. Olsen, D. A. Stahl, M. L. Sogin, and N. R. Pace. 1985. Rapid determination of 16 S ribosomal RNA sequences for phylogenetic analyses. Proc. Nat1. Acad. Sci. USA 82:6955-6959.

31. Larsen, N., G. J. Olsen, B. L. Maidak, M. J. McCaughey, R. Overbeek, T. J. Macke, T. L. Marsh, and C. R. Woese. 1993. The Ribosomal Database Project. Nucleic Acids Res. 21:3021-3023.

32. Louws, F. J., D. W. Fulbright, C. T. Stephens, and F. J. de Bruijn. 1994. Specific genomic fingerprints of phytopathogenic Xanthomonas and Pseudomonas pathovars and strains generated with repetitive sequences and PCR. Appl. Environ. Microbiol. 60:2286-2295.

33. Mulder, E. G. 1989. Sheathed bacteria-genus Haliscomenobacter, p. 20032004. In J. T. Staley, M. P. Bryant, N. Pfennig, and J. G. Holt (ed.), Bergey's manual of systematic bacteriology, vol. 3. Williams and Wilkins, Baltimore.

34. Mulder, E. G. 1989. Sheathed bacteria-genus Leptothrix, p. 1998-2003. In J. T. Staley, M. P. Bryant, N. Pfennig, and J. G. Holt (ed.), Bergey's manual of systematic bacteriology, vol, 3. Williams and Wilkins, Baltimore.

35. Mulder, E. G. 1989. Sheathed bacteria-genus Sphaerotilus, p. 1994-1998. In J. T. Staley, M. P. Bryant, N. Pfennig, and J. G. Holt (ed.), Bergey's manual of systematic bacteriology, vol. 3. Williams and Wilkins, Baltimore.

36. Mulder, E. G., and P. Hirsch. 1989. Sheathed bacteria, p. 1994-2008. In J. T. Staley, M. P. Bryant, N. Pfennig, and J. G. Holt (ed.), Bergey's manual of systematic bacteriology, vol. 3. William and Wilkins, Baltimore.

37. Murray, R. G. E., D. J. Brenner, R. R. Colwell, P. De Vos, M. Goodfellow, P. A. D. Grimont, N. Pfennig, E. Stackebrandt, and G. A. Zavarzin. 1990. Report of the Ad Hoc Committee on Approaches to Taxonomy within the Proteobacteria. Int. J. Syst. Bacteriol. 40:213-215.

38. Olsen, G. J. 1988. Phylogenetic analysis using ribosomal RNA. Methods Enzymol. 164:793-812.

39. Olsen, G. J., D. J. Lane, S. J. Giovannoni, N. R. Pace, and D. A. Stahl. 1986
Microbial ecology and evolution: a ribosomal RNA approach. Annu. Rev. Microbiol. 40:337-365.

40. Pringsheim, E. G. 1949. Iron bacteria. Biol. Rev. Camb. Philos. Soc. 24:200245.

41. Saitou, N., and T. Imanishi. 1989. Relative efficiencies of the Fitch-Margoliash, maximum parsimony, maximum likelihood, minimum evolution, and neighbor-joining methods of phylogenetic tree construction in obtaining the correct tree. Mol. Biol. Evol. 6:514-525.

42. Sambrook, J., E. F. Fritsch, and T. Maniatis. 1989. Molecular cloning: a laboratory manual, 2nd ed. Cold Spring Harbor Laboratory Press, Cold Spring Harbor, N.Y.

43. Sanger, F. S., S. Nicklen, and A. R. Coulson. 1977. DNA sequencing with chain-terminating inhibitors. Proc. Natl. Acad. Sci. USA 74:5463-5467.

44. Siering, P. L., and W. C. Ghiorse. 1994. Development and application of $16 \mathrm{~S}$ rRNA-targeted probes for detection of iron- and manganese-oxidizing sheathed bacteria in environmental samples, abstr. N-154, p. 342. In Abstracts of the 94th General Meeting of the American Society for Microbiology 1994. American Society for Microbiology, Washington, D.C.

45. Sourdis, J., and M. Nei. 1988. Relative efficiencies of the maximum parsimony and distance-matrix methods in obtaining the correct phylogenetic tree. Mol. Biol. Evol. 5:298-311.

46. Stackebrandt, E., and B. M. Goebel. 1994. Taxonomic note: a place for DNA-DNA reassociation and 16S rRNA sequence analysis in the present species definition in bacteriology. Int. J. Syst. Bacteriol. 44:846-849.

47. Swofford, D. L. 1991. PAUP: phylogenetic analysis using parsimony, version 3.0s. Illinois Natural History Survey, Champaign.

48. Swofford, D. L., and G. J. Olsen. 1990. Phylogeny reconstruction, p. 411-515. In D. M. Hillis and C. Moritz (ed.), Molecular systematics. Sinauer Associates, Inc., Sunderland, Mass.

49. Versalovic, J., T. Koeuth, and J. R. Lupski. 1991. Distribution of repetitive DNA sequences in eubacteria and application to fingerprinting in bacterial genomes. Nucleic Acids Res. 19:6823-6831.

50. Ward, D. M., M. M. Bateson, R. Weller, and A. L. Ruff-Roberts. 1992. Ribosomal RNA analysis of microorganisms as they occur in nature, p. 219-286. In K. C. Marshall (ed.), Advances in microbial ecology. Plenum Press, New York.

51. Wayne, L. G., D. J. Brenner, R. R. Colwell, P. A. D. Grimont, O. Kandler, M. I. Krichevsky, L. H. Moore, W. E. C. Moore, R. G. E. Murray, E. Stackebrandt, M. P. Starr, and H. G. Trüper. 1987. Report of the Ad Hoc Committee on Reconciliation of Approaches to Bacterial Systematics. Int. J. Syst. Bacteriol. 37:463-464

52. Weisburg, W. G., S. M. Barns, D. A. Pelletier, and D. Lane. 1991. 16S ribosomal DNA for phylogenetic study. J. Bacteriol. 173:697-703.

53. Willems, A., M. Gillis, and J. De Ley. 1991. Transfer of Rhodocyclus gelatinosus to Rubrivivax gelatinosus gen. nov., comb. nov., and phylogenetic relationships with Leptothrix, Sphaerotilus natans, Pseudomonas saccharophila, and Alcaligenes latus. Int. J. Syst. Bacteriol. 41:65-73.

54. Wilson, K. H., R. B. Blitchington, and R. C. Greene. 1990. Amplification of bacterial $16 \mathrm{~S}$ ribosomal DNA with polymerase chain reaction. J. Clin. Microbiol. 28: 1942-1946.

55. Woese, C. R. 1987. Bacterial evolution. Microbiol. Rev. 51:221-271.

56. Wong, F. Y. K., E. Stackebrandt, J. K. Ladha, D. E. Fleischman, R. A. Date, and J. A. Fuerst. 1994. Phylogenetic analysis of Bradyrhizobium japonicum and photosynthetic stem-nodulating bacteria from Aeschynomene species grown in separated geographical regions. Appl. Environ. Microbiol. 60:940946. 